\title{
Vilma Mikašytè
}

Kaunas University of Technology, Lithuania

\section{IS THE SAMOGITIAN DIALECT GOING TO DIE OUT? IMPLICATIONS OF SHOWING PRIDE IN BEING A SAMOGITIAN AND ATTITUDES TOWARDS SAMOGITIANNESS ON SAMOGITIAN FACEBOOK PAGES}

Summary. Lithuanian linguists believe that dialects in Lithuania are under threat of extinction. Many scholars who strive for language maintenance around the world suggest that the Internet provides free and unlimited possibilities to promote and maintain endangered or lesser spoken linguistic varieties. One of the dialect speaker groups in Lithuania, Samogitians, explore the aforementioned possibilities as they have recently become very active on social media. They promote the dialect and numerous Samogitian items as well as discuss various issues about their dialect and identity. The article analyzes the elements of the Samogitian identity as it is portrayed on various Samogitian pages on Facebook. The study employs several approaches, including Language maintenance, Cybercultures, and Discourse Analysis. The results reveal that the essential element of the Samogitian identity is their dialect due to which, in spite of the increasing moral and financial support, the speakers of the variety still feel stigmatized. Nevertheless, people who speak Samogitian support each other in using the dialect and promoting it not only on the Internet but in 'real' life as well. Since many Samogitians are proud of speaking the dialect and being Samogitian, it is a positive sign for the future maintenance, and social media is one of the most effective means through which it can be achieved.

Keywords: Samogitian, Facebook, dialect maintenance, identity.

\section{Introduction}

All over the world many linguists and scholars work on maintaining and salvaging threatened, endangered, or dying languages. However, there is a lack of focus on dialects; they are of equivalent importance as languages are, and they can encounter similar problems when it comes to their vitality. Nettle and Romaine state that 'every language has its own window to the world' (2000, p. 14). The same can be applied to dialects because, very often, they differ from what is considered to be the standard not only in phonology or lexis, but the speakers also share a different culture and traditions. When dialects become threatened, it is as if the aforementioned window to the world starts shrinking and people lose what Edwards (2001, p. 48) calls 'cultural distinctiveness' and knowledge about 
the world (Hymes in Nettle and Romaine, 2000, p. 197). If dialects are maintained, the vast sources of cultural information will not disappear, which will add to sustaining multilingualism.

It is common that dialect speakers are less self-confident or have to choose between speaking the dialect or the 'normal' code - the standard because of, for instance, the social and cultural pressure from the dominant group (Crystal, 2000, p. 84; Nettle and Romaine, 2000, p. 7; Kalnius, 2012, pp. 306307). One of such cases can be seen in Lithuania when it comes to one of its dialects - Samogitian. Despite various attempts to promote this variety, the Lithuanian linguists (e.g. Girdenis and Pabrèža, 1998, p. 12; Kalnius, 2012; Vaicekauskienè, 2012, p. 60) are not very optimistic about its future.

Since Samogitian differs from another Lithuanian dialect, Aukštaitian, to a very large extent, it has received probably the most scholarly interest compared to other linguistic varieties in Lithuania. In general, the studies on the Samogitian dialect range from investigations on its features to ethnic identity and attitudes towards the variety or its speakers (e.g. Ramonienè, 2010, 2013; Kalnius, 2012). The most commonly applied data collection methods include interviews, questionnaires or analysis of various literary and historical sources. However, many areas of the sociolinguistic studies in Lithuania are still underresearched when it comes to the digital media. Public discourse that appears, for instance, on social media, can also reflect the attitudes towards dialects, display elements of identities, reveal variation and vitality of linguistic varieties, and much more. This paper provides an example of how data retrieved from social media (Facebook in particular) can be approached in Language Maintenance studies.

\section{The Aim and Scope}

The aim of the investigation is to discuss the elements of the Samogitian identity as they are portrayed on the Samogitian Facebook groups and to highlight the attitudes towards Samogitianness and the preservation of the dialect. Several objectives have been formulated to reach the ends of the research. They are the following: (a) to identify what elements of the Samogitian identity are as displayed on the social network Facebook; (b) to observe the (linguistic) behavior of Samogitians as a cybercommunity; and (c) to reveal the attitudes towards 
IS THE SAMOGITIAN DIALECT GOING TO DIE OUT? IMPLICATIONS OF SHOWING PRIDE IN BEING A SAMOGITIAN AND ATTITUDES TOWARDS SAMOGITIANNESS ON SAMOGITIAN FACEBOOK PAGES

Samogitianness, Samogitians, and their dialect. Large amounts of textual and visual data were collected, but since this paper has a limiting format, only the data that are directly relevant to the research questions will be discussed.

\section{Data and Methods}

To achieve the objectives of this study, various posts and comments from eight groups which share Samogitian-related content on the social network Facebook were collected in the time span ranging from October 2015 to March 2016. The largest part of the data comes from the first group listed in the table below. It was chosen because it is quite well-known for sharing Samogitian content thatis not only entertaining but also encourages to use the dialect and instills pride in its speakers. Other groups, albeit not so famous, also share information in Samogitian and raise awareness about various Samogitian matters. As can be seen from Table 1, the interest in Samogitian Facebook groups is still growing, which indicates that the dialect and information in/about it is also becoming more and more relevant.

Table 1.

\section{Data sources}

\begin{tabular}{|c|c|c|c|c|}
\hline Original title & $\begin{array}{c}\text { Title in } \\
\text { Standard } \\
\text { Lithuanian }\end{array}$ & Title in English & $\begin{array}{c}\text { Likes in } \\
\text { March } \\
2016\end{array}$ & $\begin{array}{c}\text { Likes in } \\
\text { March } \\
2017\end{array}$ \\
\hline $\begin{array}{l}\text { Kalbiek } \\
\text { Žemaitiškā }\end{array}$ & $\begin{array}{l}\text { Kalbėk } \\
\text { žemaitiškai }\end{array}$ & Speak Samogitian & 58236 & 91338 \\
\hline \multicolumn{2}{|c|}{$\begin{array}{l}\text { Telšiai - Lietuvos kultūros sostinè } \\
2016 \text { (now: Telšiai kultūra) }\end{array}$} & $\begin{array}{l}\text { Telšiai, the Lithuanian } \\
\text { Cultural Capital } 2016 \\
\text { (now: Telšiai culture) }\end{array}$ & 4223 & 7367 \\
\hline \multicolumn{2}{|c|}{ Žemaičiu kultūros draugija } & $\begin{array}{l}\text { Samogitian Cultural } \\
\text { Association }\end{array}$ & 2403 & 2903 \\
\hline \multicolumn{2}{|c|}{ Žemaičiai - žemaičiui } & $\begin{array}{l}\text { Samogitians to a } \\
\text { Samogitian }\end{array}$ & 1774 & 2053 \\
\hline $\begin{array}{l}\text { Rokounamuos } \\
\text { žemaitėškā }\end{array}$ & $\begin{array}{l}\text { Kalbamès } \\
\text { Žemaitiškai }\end{array}$ & We Speak Samogitian & 954 & 1003 \\
\hline Ruoda & Kalba & Language & 851 & 892 \\
\hline \multicolumn{2}{|c|}{ Žemaičiu kultūros savastys } & $\begin{array}{l}\text { The Essence of the } \\
\text { Samogitian Culture }\end{array}$ & 259 & 291 \\
\hline $\begin{array}{l}\text { Žemaitiu kalba } \\
24 / 7\end{array}$ & $\begin{array}{l}\text { Žemaičiu kalba } \\
24 / 7\end{array}$ & $\begin{array}{l}\text { Samogitian Language } \\
24 / 7\end{array}$ & 89 & 318 \\
\hline \multicolumn{3}{|r|}{ In total: } & 68789 & 106165 \\
\hline
\end{tabular}


The collection of data was a process of going through all the posts and comments on the abovementioned public Facebook groups from the date of their launching to March 2016. Instead of using random sampling, the data were selected manually according to one criterion: the content or the reactions (in a form of comments) had to be relevant to the study. It is necessary to note that, following various suggestions on ethics of using publicly available data from the Internet (e.g. Rodham and Gavin, 2006, pp. 94-95; Rosenberg, 2010, p. 24) and considering the nature of the data sources (i.e. their public accessibility), written consents were not obtained prior to collecting the data. Nevertheless, whenever illustrative examples are used in the analytical part of the paper, the personal information is anonymized. It is also noteworthy that the comments appear in their original form, without correcting typos or grammatical errors.

The present study is qualitative. The research objectives will be approached by using the framework of Language Maintenance to reveal how the social media helps to encourage the use of the dialect. In addition, Discourse Analysis, in combination with the framework of Cybercultures, will aid to discuss the features of electronic discourse as well as behavior of Samogitians as an online community.

\section{Theoretical Overview}

\section{Samogitian as one of the Lithuanian Dialects}

In the Lithuanian language two major dialects are distinguished, namely Aukštaitian (High Lithuanian) and Samogitian (Žemaitian, also Low Lithuanian and Lowland dialect) (Balode and Holvoet, 2001, p. 51). The latter is spoken in the north western parts of Lithuania, whereas the Aukštaitian dialect dominates the rest of the country (see the map below). Despite the linguists' classification, in vernacular, Lithuanians usually differentiate between more than two dialects. Studies show that people tend to identify their dialects according to the ethnographical regions that they come from - Aukštaitija, Samogitia (or Žemaitija), Dzūkija, Suvalkija, and Lithuania Minor (Baranauskienè \& Krupickaitè, 2012, pp. 2-3). However, Baranauskienè and Krupickaitè 
IS THE SAMOGITIAN DIALECT GOING TO DIE OUT? IMPLICATIONS OF SHOWING PRIDE IN BEING A SAMOGITIAN AND ATTITUDES TOWARDS SAMOGITIANNESS ON SAMOGITIAN FACEBOOK PAGES

(2013, p. 44) note that in vernacular, people usually refer to only four dialects; that is, Aukštaitian, Samogitian (or Žemaitian), Dzūkian, and Suvalkietian.

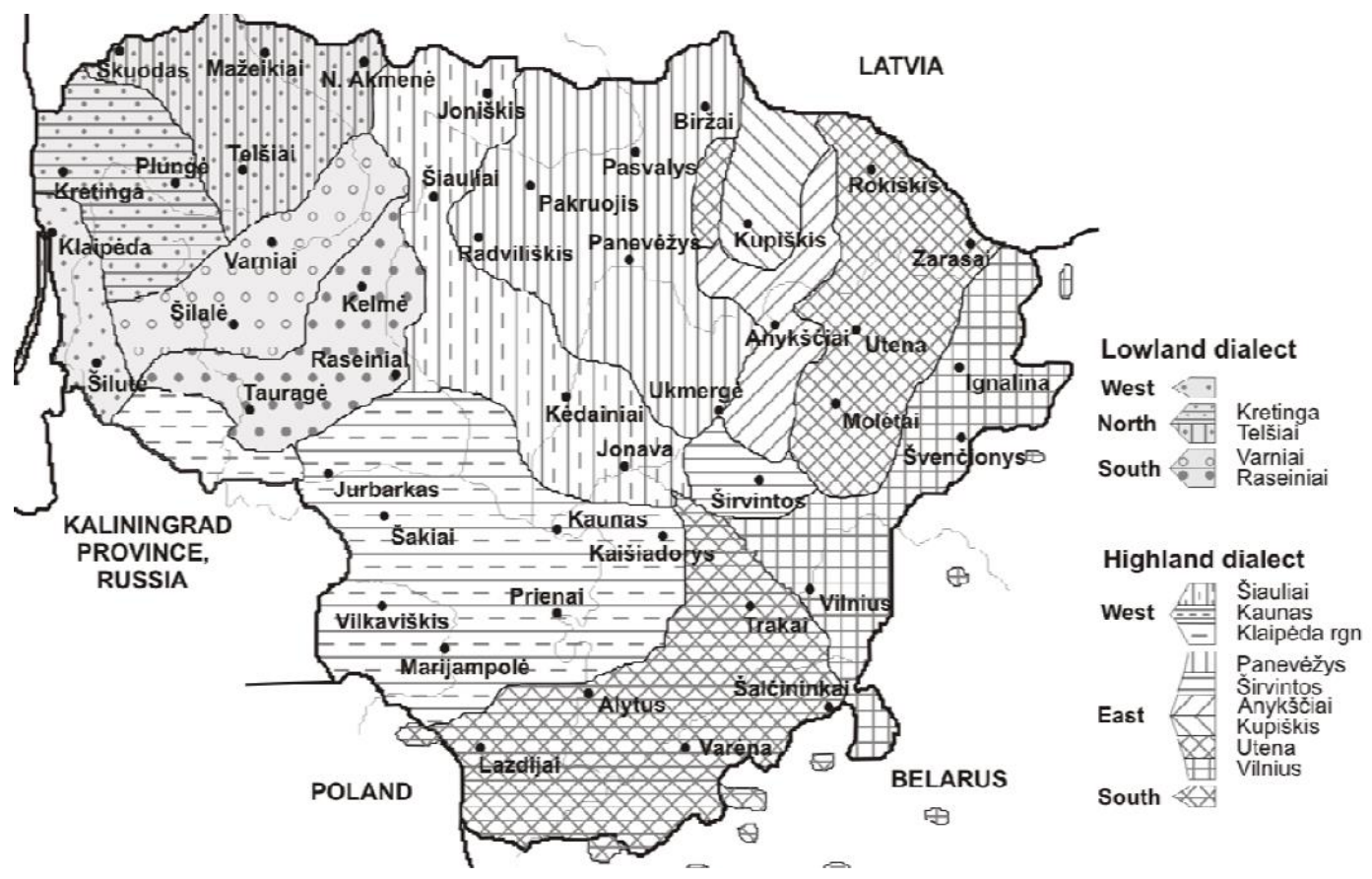

Map 1. The Lithuanian dialects and subdialects

(the Lithuanian Language Institute 2005 in Vaicekauskienè, 2011, p. 105).

According to Girdenis and Pabrèža, various historical sources describe Samogitians and Aukštaitians (sometimes referred to as Lithuanians) as 'two distinct territories, groups, even tribes with their own culture, customs, ethnography, and so on' (1998, p. 10). Therefore, it should come as no surprise that they speak different varieties even to this day (Baltenas \& IvanauskaitèŠeibutienè, 2012, p. 7; Girdenis \& Pabrèža, 1998, p. 10). Lithuanian linguists differentiate between them along the lines of the phonetic cues. Furthermore, even though Samogitian does not have an established standard, it has subdialects; their classification depends on the Cardinal Directions or how the diphthong in the word duona [Eng. bread] is pronounced, hence dounininkai, dūnininkai, and donininkai [emphasis added] (Girdenis \& Pabrèža, 1998, p. 12). In other sources (e.g., Vaicekauskienè, 2011) they are classified as west, north, 
Vilma MIKAŠYTĖ

and south Samogitian. The difference in the stem diphthongs also indicates that there is variation in the dialect and the subdialects may not always be mutually intelligible.

Much of the research body on the Lithuanian dialects stresses the differences between pronunciation, but it is nonetheless very important to mention dissimilarities in the vocabulary and, to some extent, morphology (see Girdenis \& Pabrèža, 1998, p. 47). As several investigations (e.g. Ramonienè, 2010, 2013; Krupickaitè \& Baranauskienè, 2013, p. 44) reveal, Samogitian is unanimously evaluated as the most incomprehensible linguistic variety of the Lithuanian language. Maybe because of the differences in phonetics, vocabulary, and morphology, in vernacular some people call Samogitian a separate language. However, the Lithuanian linguists have agreed upon referring to the variety, which is spoken in the ethnographical region of Samogitia, as a dialect (Kalnius, 2012). It is important to note that the present study does not answer the research questions by taking into account all the subdialects but looks at the Samogitian dialect as a whole.

\section{Attitudes towards Dialects in Lithuania}

One of the essential elements in the vitality of a dialect is people's (especially the young generation's) stand on its maintenance. Studies on the attitudes towards dialects in Lithuania reveal that teenagers and young adults often feel ashamed of their dialect; the less similar it is to the Standard Lithuanian (further - SL), the more embarrassed they feel about it (Taraškevičius, 2009 in Baranauskienè \& Krupickaitè, 2012, p. 16; Ramonienè, 2013, p. 6). If there is a rather great distance between any given variety and the standard, the former is evaluated as incorrect or even as not 'normal' (Ramonienè, 2013, pp. 6, 11, 12; Kalnius 2012, pp. 306-307). Moreover, a dialect speaker, who uses this supposedly 'incorrect' code, is seen as an uneducated person (Taraškevičius, 2009 in Baranauskienè \& Krupickaitè 2012, p. 16; Ramonienè, 2013, p. 85; Krupickaitè \&Baranauskienè, 2013, p. 41). Therefore, the potential dialect speakers, for example, Samogitians, have to decide whether to learn the dialect and sustain it or speak the 'normal' language to avoid being labeled (Kalnius, 2012, pp. 306-307). 
IS THE SAMOGITIAN DIALECT GOING TO DIE OUT? IMPLICATIONS OF SHOWING PRIDE IN BEING A SAMOGITIAN AND ATTITUDES TOWARDS SAMOGITIANNESS ON SAMOGITIAN FACEBOOK PAGES

There are several explanations for how the equation between speaking the standard and being educated came to the Lithuanians' minds. According to one of them, it dates back to the beginning and the latter half of the twentieth century, when access to higher education was limited and those few educated people spoke the standard, hence the association (Bajarūnaitè \& Liauksminas, 2013). Another version is linked to the interwar period as well as the heritage of the Soviet occupation era. The SL emerged over one hundred years ago, and during the interwar period, when Lithuania was an independent country (19181940), an important task was to rid it from the influence of other languages (Vaicekauskienè, 2011, pp. 105-106). In other words, the aim was to purify it, which points to conservative attitudes towards the language. Moreover, the SL was expected to be homogenous, thus variation was not desired (Subačius, 2002). In addition, under the Soviet rule, language planning policies valued 'pure' language (Vaicekauskienè, 2011, p. 107). The Commission for the Lithuanian language was also launched and given the role to 'establish the trends and tasks of the state language protection and approve linguistic norms' (The Law on the State Language, 1995). Lithuanian scholars, for example, Vaicekauskienè (2011, p. 108; 2012, p. 60), note that due to the norms and 'correctness' of the standard variety, the interference of the dialects (as well as other languages) and linguistic diversity are still not really welcome.

It is very important for a dialect to have prestige; the more prestigious it is, the more perceived value it has and the more likely it will be sustained. As previous investigations show, there are around $26 \%$ of young Samogitians who believe that their dialect is prestigious, but Aukštaitian is still the most prestigious variety in Lithuania (which is probably because the SL is based on one of the subdialects of Aukštaitian) (Kliukienè, 2014). Despite the evaluated prestige and diverse attitudes towards dialects, it is clear that people are in favor of dialect use only in certain domains. For example, Ramonienè (2013, p. 7) indicates that dialects only have place in private domains, so speaking a dialect in an official context is inappropriate. Even the use of the most prestigious dialect, Aukštaitian, is acceptable in a restricted variety of contexts; to be more precise, private and semi-private, but not the public domain (i.e. the media, education, and business) (Ramonienè, 2013, p. 82). Regardless of the abovementioned attitudes, dialects, 
Vilma MIKAŠYTĖ

especially Samogitian, occur in a variety of (public) domains, which is one of the positive indicators for its future maintenance.

\section{Public Perceptions of Samogitians and Samogitianness}

According to probably the most extensive piece of academic literature on Samogitians, Žemaičiai: XX a. - XXI a. pradžia [Eng. Samogitians: twentieth the beginning of the twenty-first century], it has been estimated that there might be from around 200000 up to 600000 Samogitians in Lithuania (Kalnius, 2012, pp. 132, 143, 144). There have been many discussions on who Samogitians are. Kalnius (2012, p. 9) explains that there are different attitudes towards Samogitians and Samogitianness. There seems to be a tendency to support the viewpoint, according to which the Samogitian identity is similar to Lithuanian, their traditional culture is part of the Lithuanian culture, hence Samogitians are part of the nation (Kalnius, 2012). As Kalnius (2012, p. 288) states, Samogitians as well as people from other ethnographic regions respect the same state symbols, share the same history, and protect the same country. Furthermore, the results of Kalnius' research in 2001-2003 show that 96\% of Samogitians consider themselves to be Lithuanians who simply use a different code (Kalnius, 2012, p. 288). Despite various hypotheses and scholarly arguments, it is essential to take into account how the members of the community feel.

In general, the investigations on self-identification with the Lithuanian dialects reveal that the most important aspect which determines whether a person belongs to the community is the ability to speak the dialect (Kalnius, 2012, pp. 172, 173, 298). Likewise, $82 \%$ of the Samogitian respondents in Kalnius' (2012, p. 173) study claim that the determining factor by which a person can ascribe him/herself to Aukštaitians, Dzūkians, or Suvalkietians, is indeed being able to speak the dialect. In other words, the distinction between 'us' and 'the Other' depends on one's linguistic competences.

In addition to speaking the dialect, there are other important aspects to the Samogitian identity as well. If any Lithuanian was asked about the most typical feature of the Samogitian nature, there is a very high chance that they would stereotypically mention stubbornness. Kalnius (2012, p. 258) points out that this mental link between being Samogitian and being stubborn is so 
IS THE SAMOGITIAN DIALECT GOING TO DIE OUT? IMPLICATIONS OF SHOWING PRIDE IN BEING A SAMOGITIAN AND ATTITUDES TOWARDS SAMOGITIANNESS ON SAMOGITIAN FACEBOOK PAGES

prevalent and generalized that it seems as if this quality is encoded in all Samogitians' genes. Scholars explain that Samogitians are seen as persistent because even under various difficult historical circumstances, they clung to their dialect and refused to speak any other variety (Girdenis \& Pabrèža, 1998, p. 10; Kalnius, 2012). Interestingly enough, Kalnius' (2012, pp. 270-271) investigation does not reveal the abovementioned tendencies, but the results show that Samogitians themselves believe that they are stubborn. Samogitians are also said to have a firm and clear position in conducting various matters (Baltrénas \& Ivanauskaitè-Šeibutienè, 2012, p. 17). Similarly, they are supposed to be physically strong and hard-working (Kalnius, 2012, p. 258; Baltrénas \& Ivanauskaitè-Šeibutienè, 2012, p. 8), which is very much what some Samogitians claim to be really true. In the light of the aforementioned opinions and stereotypes, one could say that it is not so easy to produce a precise portrait of a 'true' Samogitian, especially when there are so many Samogitians who, as Kalnius (2012) suggests, are not sure of who they are themselves.

\section{Identity and Cyberspace}

A number of scholars claim that language is an inseparable part of people's identity (e.g. Kamusella, 2001, p. 241). Some even believe that an identity is 'an entirely linguistic construction' (Grossberg, 1996, p. 90). It is important to mention that there are several issues in relation to the concept of identity. Scholars note that the contemporary idea of an identity has changed, so it is now accepted that identities are flexible, unstable, fragmented, incoherent, and even contradictory, also very often described as 'fluid' (Butler, 1990; Hall, 2000 in Nayar, 2010, p. 14; Hall, 1996, p. 4; Grossberg, 1996, pp. 89, 91). Moreover, the Internet provides the possibility to remain anonymous and choose whatever online identity (which is often referred to as avatar) that one wishes to exhibit (Turkle, 1995). Similarly, Turkle (1995, p. 180) adds that the Internet provides the freedom to adopt, create, and reconstruct various identities according to whatever fashion that one likes. In other words, the Internet enables identity play (Vandergriff \& Fuchs, 2009, p. 28). 
All of the aforementioned identities, whether they are 'real' or made up, can appear or be exhibited via cybercultures. According to Nayar, cybercultures are 'the articulation between hardware [machines, computers, cable networks], software [programs], and wetware [humans], all three of which are deeply embedded in the social historical contexts of the technology' (2010, pp. 26-27). Furthermore, cybercultures have different forms and genres, such as the Internet, fan works, various types of cyber art, games, and social networking (Nayar, 2010, p. 31). Another important concept when it comes to cybercultures is cyberspace, which, as Rheingold puts it, is 'the conceptual space where words, human relationships, data, wealth, and power are manifested by people using CMC [Computer-Mediated Communication] technology' (1993, p. 6). Since it allows sharing all kinds of content and establishing relationships, combined with the effort and initiatives of everyone, including laypeople and government, cyberspace has the potential to preserve or rebuild cultural diversity (Rheingold, 1993, p. 9). This suggests that it could help to keep the balance in sustaining linguistic diversity as well.

The Internet enables the mobilization of various support networks and resources; it also allows people to get involved in various social and cultural initiatives (Zimbra, Abbasi, \& Chen, 2010, p. 54). Moreover, it can be employed as a tool for (re)shaping culture and involving people into the process via public discourse and interaction (Johnston \& Klandermans, 1995, pp. 5, 9, 23). Virtual communities 'are often vibrant with strong membership and robust communication, containing discourse that is highly revealing of the perspectives and ideologies of the social movement' (Zimbra et al., 2010, p. 54). Communities can not only become more visible but also devise new ways to preserve their culture as well as add a modern touch to it to make it more appealing to different generations and out-groups. Despite the disbelief in the authenticity of the identities online (Wilbur, 2000), this study supports the previous research of scholars who claim that cyberspace actually enables any person to express various cues of their true identity (Nayar, 2010) and work together for achieving causes that are important to them. 
IS THE SAMOGITIAN DIALECT GOING TO DIE OUT? IMPLICATIONS OF SHOWING PRIDE IN BEING A SAMOGITIAN AND ATTITUDES TOWARDS SAMOGITIANNESS ON SAMOGITIAN FACEBOOK PAGES

\section{Discussion of the Findings}

\section{Reactions to Samogitians and their Dialect on Facebook}

In general, the main tendency is that visitors who are not Samogitian express positive attitudes and show support to the dialect and its speakers. There is only a handful of negative comments. However, the author is aware that this might be due to one of the limitations of the study - the administrators of the Samogitian Facebook groups can manage the content as they wish, hence the negative comments that they consider to be inappropriate might have been deleted. Nonetheless, even if there were more negative comments, they would not dramatically change the findings of this investigation. All the remarks fall into two categories: (a) comments about the dialect and (b) comments about the speakers of the dialect in focus.

It can be noted that most of the people who are in favor of the dialect, come and comment in the Samogitian Facebook groups with a purpose. Before expressing their attitudes, a lot of visitors provide some brief background to justify their position. Either people who are close to them are Samogitian or they support the dialect and linguistic variation in general. There are people who tell that they recall their grand- or great grandparents speaking Samogitian with them when they were children. However, none of these people mention their parents speaking Samogitian. This suggests that there could have been a break in the intergenerational transmission of the dialect, which might potentially be the result of the attitudes towards language variation during the Soviet period. Nevertheless, the content of the comments indicates that people's opinions about speaking the dialect are changing (at least when it comes to this particular dialect). A number of people who are not Samogitian claim that the dialect is positive, unique, interesting, and beautiful. In addition, they express their desire to learn it, '[p]ats nesu žemaitis, bet labai norèčiau išmokt grynos žemaitiškos kalbos, deja nèr iš ko mokytis' [Eng. I am not a Samogitian but I would love to learn the true Samogitian language; unfortunately, there is no one to learn it from]. Quite a few visitors admit that they managed to learn Samogitian from reading the content that is shared in the Samogitian Facebook groups. This 
suggests that the presence of Samogitian on Facebook can indeed positively impact its maintenance.

Even though many non-Samogitians claim that the dialect is beautiful, several individuals evaluate its aesthetical features negatively and express their pejorative attitudes. For example, one person claims that it would be hard to find an uglier dialect. Further, the dialect and its speakers are ridiculed in the feedback on Samogitian jokes, 'bajeriai tai ne kazka...bet kai parasyta zemaitiskai tai vistiek juokinga' [Eng. The jokes are not particularly good but it is nonetheless funny because they are written in Samogitian]. Moreover, one individual inquires whether these are the Lithuanians who did not manage to learn Latvian in the shoe factory of Riga. Such disdain for the dialect suggests that the variety in focus does not really belong to the Lithuanian language or is an incorrect version of it. Therefore, some people see the dialect and its speakers as abnormal, '[n]egeriau ut viiems normaliems lietuviams, kam reikia tu žemaičiu kalbos.' [Eng. Would it not be better for everyone to be normal Lithuanians? Why is this Samogitian language necessary?]. Unlike in Kalnius' (2012) study, Aukštaitians on the Samogitian Facebook groups do not express any negative attitudes towards Samogitians as individuals (except for the supposed 'abnormality'); they mostly ridicule the Samogitian dialect and its features.

Other Aukštaitians react to such ideas negatively and sympathize with Samogitians. For instance, one of such supporters states that normal people do not depreciate languages and dialects. Moreover, people claim that Samogitians ought to be proud of their dialect and of being Samogitian. Pro-Samogitian visitors of these groups acknowledge that it is important to preserve the dialect because, for example, even the SL is under threat due to the influence of the English language, '[t]armes yra grazu ir jas reik saugot! Nes tuoj Lietuviai ne tik kad tarmiu nebeatskirs, bet ir lietuviskai nebemokes kalbet, nes kas antras zodis angliskas' [Eng. Dialects are beautiful and it is necessary to preserve them. That is because Lithuanians will soon be unable to tell them apart and also cease to know Lithuanian as every other word is in English]. Some Aukštaitians express similar puristic attitudes; they recognize that the Samogitian dialect is not pure anymore, the reason being TV, newspapers, and the standards of the SL. Ironically, as many Samogitians note, such comments are written with an abundance of grammar and spelling mistakes in the SL. 
IS THE SAMOGITIAN DIALECT GOING TO DIE OUT? IMPLICATIONS OF SHOWING PRIDE IN BEING A SAMOGITIAN AND ATTITUDES TOWARDS SAMOGITIANNESS ON SAMOGITIAN FACEBOOK PAGES

\section{The Key Feature of the Samogitian Identity}

The most important aspect of the Samogitian identity, as it is emphasized throughout the different content and comments on the Samogitian Facebook groups, is being able to speak the dialect. A large part of the posts shared by the Samogitian Facebook groups revolve around the Samogitian dialect, its features, and various issues in relation to it. As a cybercommunity, Samogitians quite unanimously express their respect to the dialect, to which they actually refer as kalba - a language. For instance, one person asks, '[k]oks žemaitis žemaičiu kalba gali vadint tarme?' [Eng. What kind of Samogitian can call the Samogitian language a dialect?]. Many Samogitians provide their arguments on why Samogitian is a language (most of them are connected to the linguistic variation). Finally, one of the Samogitian Facebook groups explains that for Samogitians, it is a language because it has dialects of its own; other people decided for them to classify it as a dialect but Samogitians stick to their own rules.

A lot of Samogitians also evaluate the aesthetical qualities of the dialect; they claim that it is beautiful and very rich. Some of them even believe that Samogitian is the most beautiful language in the world. The adjective 'beautiful' appears to be among the most frequent adjective collocations of 'Samogitian'. Even though some speakers of the dialect in focus admit that it has shifted and may not always be pure, they still prefer to speak it and, as many put it, not to break their tongues when trying to speak Aukštaitian (also referred to as Lithuanian and the literary language).

Samogitians identify their dialect as a normal means of communication. Moreover, they are sometimes very sensitive to when others express the opposite opinion. Several comic strips even depict how people who criticize the dialect are punished for it, e.g., a boy gets beaten up for calling Samogitians village people, and a girl gets offered to burn herself for questioning why Samogitians cannot speak the normal language. In addition, a man is supposedly killed for saying that he has never heard such a rustic language in his entire life. The term that the person employs to describe what he hears, kaimietiška, is highly negatively loaded in Lithuanian and refers to someone of low socioeconomic status or somebody with a lack of education. By means of exaggeration and dark humor in 
the posts and comments, Samogitians indicate that they cherish their dialect and do not want to experience any language-based bullying.

Samogitians who comment on the abovementioned images share a similar point of view. For example, people tag their friends under such posts and ask them not to forget the normal language (meaning Samogitian) when they come back after studying in other cities of Lithuania. This shows that there is antagonism between Samogitians and Aukštaitians when it comes to how they perceive what the most acceptable code for communication is. Either side sees their variety as normal hence prestigious, which places the other variety in the reversed position. Therefore, when Samogitians switch to using the $\mathrm{SL}$, fellow Samogitians sometimes feel like slapping them, 'is kart nuors y i kram dout' [Eng. There's an urge to hit someone's head]. Moreover, a rather commonly expressed idea suggests that if a Samogitian does not speak or understand the dialect, s/he is a poor Samogitian or not a Samogitian at all.

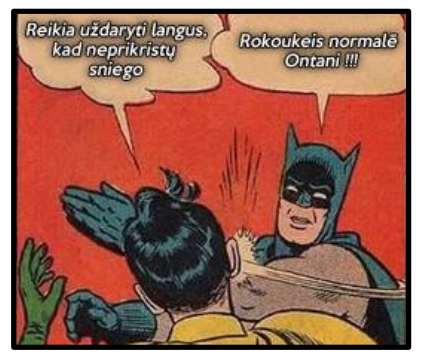

Pic. 1. Reaction to SL

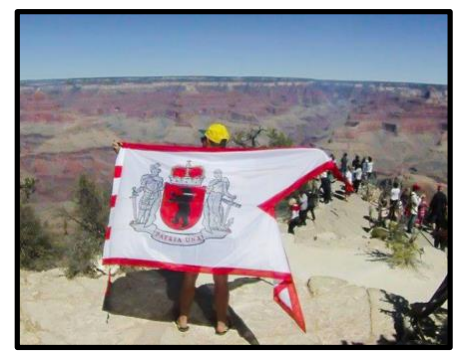

Pic. 2. A proud Samogitia

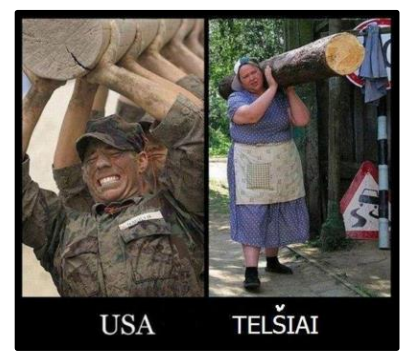

Pic. 3. A strong Samogitian

As Samogitians report, they are so much in favor of their dialect that they put up public signs in it as well. It suggests that there is an opposition between Samogitian and the SL in the public domain; Samogitian takes place of the SL to perform various functions that are typically fulfilled only by the SL. The domains where the dialect is used are expanding from bottom-up, so this could be interpreted as a shift in Samogitians' perceived value of their dialect. They do not believe that it is suitable only for the private domain anymore. However, this cannot ensure that people will speak Samogitian in those areas where these signs appear. For example, one Samogitian claims that she lives in the middle of the region but people in her area only speak the SL. Conversely, quite a few 
IS THE SAMOGITIAN DIALECT GOING TO DIE OUT? IMPLICATIONS OF SHOWING PRIDE IN BEING A SAMOGITIAN AND ATTITUDES TOWARDS SAMOGITIANNESS ON SAMOGITIAN FACEBOOK PAGES

Samogitians claim that they cling to their dialect regardless of where they are or whom they talk to, '[a]s sneku tik zemaiteska su visas' [Eng. I speak only Samogitian with everyone], '[a]s i isvaziavus rokounous zemaiteska' [Eng. I speak Samogitian when I go away]. This shows that the dialect does not have solely practical functions but symbolic value as well.

Many visitors of the Samogitian Facebook groups (both Samogitian and Aukštaitian) hold prescriptivist views on the dialect. Some individuals believe that there is a need for more rules (to be more precise, standardization of the dialect), especially when it comes to the use of Samogitian in the written form. Indeed, the content of probably the largest share of the comments that comprise the dataset is related to the issues of the variation within the dialect. A lot of Samogitians argue over the 'correct' spelling or vocabulary because they are unaware that such variation actually exists. Moreover, since some people find various words unfamiliar, they feel embarrassed about not knowing their mother tongue properly or believe that they are experiencing language attrition. For example, a Samogitian expresses her amazement, '[r]eks mokyteis, paveiziejau no kad ir as nezenau tuokiu tu Zemaitesku zuodiu ... net gieda pasidar, kad nesupronto sav gimtuoses kalbuos' [Eng. I will have to learn too; I looked at it and I do not know such Samogitian words ... it made me feel ashamed that I do not understand my mother tongue]. This shows that even though Samogitians live in, as previous studies reveal, a region with a strong sense of Samogitian identity, there is a lack of education on the dialect itself. It is not enough to speak the dialect; the dialect users express the need for a more formalized approach to their variety. This indicates that the social media empowers bottom-up social movements and the accumulation of various ideas, by which people strive for change. Adding this to a sense of pride (that Samogitians openly exhibit) and perceived value may yield good results for dialect maintenance, which may also stimulate the development of sustainable multilingualism in the country.

On the other hand, Facebook posts suggest that there are more obstacles to using the dialect than simply the lack of standardization. One group uploaded a comic strip, which depicts a distressed girl, who, when asked about what happened to her, reveals that she was not allowed to speak Samogitian at school. People in the comment section share the same experiences. One Samogitian reports, 'mums aukletuoj neled snekiet zemaiteska sak fu nesnekieket tep 
Vilma MIKAŠYTĖ

negraze' [Eng. Our form master did not allow us to speak Samogitian; she told us not to speak in such an ugly manner]. This reveals that there is still a problem with the attitudes towards dialects when it comes to the educating staff at schools. Such situations may result in what is expressed by one Samogitian, '[n]u ziauriai skamba, pati esu is zemaitijis, bet raip ir nepamylau tos tarmes' [Eng. It sounds horrible; I am from Samogitia but I did not manage to fall in love with the dialect]. If teachers forbid pupils to use their mother tongue (in this case, dialect), especially due to their own poor attitudes, the students' perception of the dialect may shift to negative, which will have damaging implications for its maintenance and vitality in the future.

\section{Pride in Being Samogitian and Other Elements of the Samogitian Identity}

Many Samogitians express and emphasize their pride in being Samogitian. For instance, they upload photos of Samogitian flags in their property (erected not due to a special occasion), which is actually not typical in Lithuania at all, as opposed to, e.g. the Scandinavian countries. In addition, Samogitians proudly consume various Samogitian artefacts; they also carry the Samogitian flag or wear T-shirts with signs in Samogitian when they travel abroad (see Picture 2). Quite a few instances have been observed in which Samogitians pose for the picture as mighty conquerors of some natural objects, holding the Samogitian flag up. Furthermore, some Samogitians love their motherland and cultural heritage so much that they get the Samogitian coat of arms tattooed on their chest (as well as other body parts like the back) in red, black, and white - the colours of the Samogitian flag and coat of arms.

Samogitians almost unanimously express their positive feelings about being Samogitian in the comments section of the Samogitian Facebook groups. One Samogitian even emphasizes her joy with a triple exclamation mark, 'Kaip džiaugiuosi, kad esu žemaitè!!!' [Eng. I am so happy that I am a Samogitian]. Such sense of pride also triggers some discussions on what the Samogitian identity is. As another Samogitian puts it, a person cannot be Lithuanian and Samogitian at the same time; when it comes to identity and ethnic identity, if a Samogitian is affected by the Lithuanian assimilation and has lost his/her 
IS THE SAMOGITIAN DIALECT GOING TO DIE OUT? IMPLICATIONS OF SHOWING PRIDE IN BEING A SAMOGITIAN AND ATTITUDES TOWARDS SAMOGITIANNESS ON SAMOGITIAN FACEBOOK PAGES

Samogitian identity, then the person considers himself/herself a Lithuanian. Several other Samogitians claim that they are not Lithuanian and their true nationality is Samogitian, "as neso ir nikumet nabuvau lietove, as nuoru kaap tautybe 'zemaite' turiet" [Eng. I am not a Lithuanian and I have never been one; I want to have 'Samogitian' as my nationality]. There are people who even reject the presence of the Lithuanian symbols in Samogitia or would like to separate from the state and establish a new country. However, such radical ideas do not get much support, and some Samogitians note that they are both, Samogitian and Lithuanian, and do not wish to be regarded as separatists.

Many people mention the Samogitian history and emphasize how great Samogitians used to be (and still are). Moreover, some of them are convinced that, for instance, 'je ne Žemaitèje i žemaitę, tuos anu bendrènès kabuos ni būt nebūto ir šnekietom daba lènkèška arba rusiška' [Eng. If it were not for Samogitia and Samogitians, the SL would not exist and people would be speaking Polish or Russian]. On the other hand, some people believe that it makes no sense to cling to the past so much; the future for Samogitians is Norway, London, and finally extinction. This indicates that it is imperative to take measures and to invest various resources into ensuring its transmission to the future generations. Pride is an important factor but it is not enough to sustain the dialect.

To summarize the abovementioned, in general, people feel proud of being Samogitian due to a variety of different reasons. The sense of pride comes from the glorious past, shared values, and, above all, the common 'language'. Another very common idea is expressed by many Samogitians who are proud to be Samogitian simply because they were born in the region. Indeed, there are several different noun synonyms that refer to the place where one was born (e.g. gimtiné, tévynè). Interestingly enough, one of these terms, the noun tévyne [Eng. fatherland/native country], is typically used when referring to the country where one was born (especially when one feels patriotic), not the region. This might also imply the earlier described antagonistic views towards being both Samogitian and Lithuanian at the same time - first comes Samogitia (so the regional identity), and only then Lithuania (the national identity). Such primodialistic views also suggest that if a person was not born in Samogitia, regardless of his/her enthusiasm or linguistic skills, s/he cannot be a 'true' Samogitian. 
Vilma MIKAŠYTĖ

Even though the central element of the Samogitian identity online is the dialect, there are also other additional qualities that are ascribed to a supposedly 'true' Samogitian. Interestingly enough, there is a dominant tendency for Samogitians and Aukštaitians to refer to someone as a 'true' Samogitian. This expression seems to be well-established; the adjective 'true' is one of the most common adjectives found in the posts and comments under them.

Table 2.

\section{Traits of a 'true' Samogitian}

Speaks Samogitian
Attached to Samogitian culture
Physically very strong
Fierce
Brave
Tough

Samogitians often insist that they are very strong physically. Even though Kalnius (2012) explains that Samogitians perceive themselves as physically strong, the findings of his research reveal the attitude towards physical strength in general, without linking it to a certain age or gender. The data from the Samogitian Facebook groups specify and emphasize that not only Samogitian males are strong but females are as well (see Picture 3). Elderly Samogitians are also portrayed as physically strong, brave, and fierce. The belief that all Samogitians are tough seems to be rooted in Samogitians' pride of their history, especially when it comes to fighting; in some comments, it is stressed that Samogitians have been mighty warriors indeed. There is a lot of emphasis not only on physical strength but also on the physical appearance. Samogitians on Facebook tend to suggest that they are more gifted in both as opposed to other people, be it Aukštaitians or foreigners. As they put it, it is enough for a person to tell that $\mathrm{s} /$ he is a Samogitian or comes from the region, and people around them instantly get interested or aroused. Most of these ideas are expressed in a multimodal fashion, via verbal text and colourful, usually humorous, images. There are many posts and pictures that do not seem very serious but the entertaining content is in many cases what makes the Samogitian Facebook groups so attractive to people of all ages and backgrounds. 
IS THE SAMOGITIAN DIALECT GOING TO DIE OUT? IMPLICATIONS OF SHOWING PRIDE IN BEING A SAMOGITIAN AND ATTITUDES TOWARDS SAMOGITIANNESS ON SAMOGITIAN FACEBOOK PAGES

\section{Conclusions}

The social network Facebook proves to be a valid means to display one's identity, develop a sense of community, and promote linguistic varieties without investing any funds. The Samogitian groups do not only share various pieces of information that is related to Samogitians and the promotion of their dialect but also express who they are as individuals as well as a community. To Samogitians as a cybercommunity, the most important value and aspect of their identity is their dialect, which they almost unanimously call a language. Many Samogitians adopt the Samogitian orthography, which is a positive sign for its maintenance. Furthermore, there is much of discussion on the (in)correctness of the dialect. Earlier investigations on the Lithuanian dialects reveal the attitudes towards them and their features. However, they do not necessarily reveal to what extent its speakers are interested in the features of the dialect or its preservation. This study shows that Samogitians care about the correctness of their dialect to a great extent, and that they are interested in changing people's attitudes towards it. Moreover, since many Samogitians are in favour of standardization of the dialect, this suggests that establishing a standard could possibly enhance the chances of its maintenance in the future. People could learn how to, in their own words, properly write in dialect. However, due to standardization some Samogitian subdialects may disappear or become even less prestigious.

The Samogitian Facebook groups are also visited by non-Samogitians. Many of them express their desire to learn the dialect, which is the main reason of their interest in Samogitian content. Several visitors express their negative attitudes towards the dialect but there are many more people who do not belong to the Samogitian community and still support the dialect and encourage to feel proud of being Samogitian. Since the dialect is visible on the Internet and there are a lot of positive comments that urge to use Samogitian without feeling insecure, more young Samogitians may see it as relevant and worth to be spoken, thus transmitted to the future generations. On the other hand, from a Samogitian perspective, such verbal support is not enough to compensate for the stigmatization that they still have to endure when communicating with Aukštaitians or even their teachers at schools. 
The study also reveals that there is a need for more education about (as well as in) dialects, which is expressed by Samogitians as a cybercommunity that is united by a common linguistic code. Numerous comments show that there are a lot of people who are unaware of the variation within Samogitian, which causes various heated discussions. In addition, several young people share their experiences from school, where they were or still are forbidden to speak the variety. This indicates that it is equally important to change the attitudes towards dialects not only when it comes to different age groups but also to people with different educational and professional backgrounds.

Samogitians are a united cybercommunity, which shows great pride in their heritage. However, even though Facebook is embedded in the walks of real life, it may not be fully representative of real life situations. That is, Samogitians might be active and passionate online, but passive and not so much enthusiastic beyond social media. Regardless of this limitation, it seems fair to say that Samogitian still has a good start when it comes to ensuring its maintenance. Some of the fundamental milestones are already achieved: many Samogitians show great pride in being Samogitian and speaking the variety, Samogitian is present on a variety of domains, young Samogitians are interested in the dialect, there are discussions about the dialect, there is frustration about dialect-based discrimination (which ignites the desire to change the situation), and Samogitians consume Samogitian artefacts. In other words, the answer to the question, posed by the famous scholar Joshua A. Fishman, 'Do they love it in their hearts?', is, as the data collected from the Samogitian Facebook groups show, 'yes'. If their pride does not cease to exist and other speakers' needs are met, the dialect is very likely to exist in the future.

Previous studies on the Lithuanian dialects mostly use the data that are collected through questionnaires and interviews with the younger generations because they are easy to approach via educational institutions. Collecting data from the Internet and investigating the contents of the e-discourse is a fascinating and still underemployed method when it comes to various Lithuanian topics. This study mostly focused on the Samogitian identity as it is portrayed on Facebook. However, it is also intriguing to analyze the different shapes of selfexpression on the Internet (e.g. the variation in spelling), to observe whether the attention to dialects will increase (and how) longitudinally, to discover which 
IS THE SAMOGITIAN DIALECT GOING TO DIE OUT? IMPLICATIONS OF SHOWING PRIDE IN BEING A SAMOGITIAN AND ATTITUDES TOWARDS SAMOGITIANNESS ON SAMOGITIAN FACEBOOK PAGES

Samogitian subdialect is the most commonly used for communication within the cybercommunities, or to carry out a similar research on the subdialects of Aukštaitian.

\section{References}

Bajarūnaitè, A., \& Liauksminas, S. (2013). Lietuviu tarmès ne nyksta, o keičiasi". Retrieved from http://www.Irt.It/naujienos/kalba_vilnius/32/17393 \#wowzaplaystart= 5795000 \&wowzaplayduration=1101000.

Balode, L., \& Holvoet, A. (2001). The Lithuanian language and its dialects. In O. Dahl \& M. Koptjevskaja-Tamm, (Eds.) Circum-Baltic Languages: Typology and Contact (pp. 41-80). Amsterdam: Jon Benjamins.

Baltènas, A., \& Ivanauskaitè-Šeibutienè, V. (2012). Žemaičiai=: Samogitians: Gyvenimai ir Šventès. Vilnius: R. Paknio leidykla.

Baranauskienè, V., \& Krupickaitè, D. (2012). Lietuvos miestu gyventoju tarminès regioninès savimonès ypatumai (sociolingvistinio tyrimo duomenimis). Taikomoji kalbotyra, 10 Retrieved from http://taikomojikalbotyra.It.azalija.serveriai.It/wpcontent/uploads/2012/10/Baranauskiene_Krupickaite_Lietuvosmiestai_20 12PDF.pdf.

Baranauskienè, V., \& Krupickaitè, D. (2013). Regioniniai kalbu vartojimo Lietuvos miestuose ypatumai. In M. Ramonienè (Ed.), Miestai ir kalbos II: sociolingvistinis Lietuvos žemèlapis (pp. 23-54). Vilnius: Vilnius UP.

Crystal, D. (2000). Language Play. Chicago: University of Chicago Press.

Edwards, J. R. (2001). Multiculturalism and language. In R. Mesthrie (Ed.), Concise Encyclopedia of Sociolinguistics (pp. 48-50). Oxford: Elsevier Science.

Girdenis, A., \& Pabrèža, J. (1998). Žemaičiu rašyba. Vilnius and Šiauliai: Žemaičiu kultūros draugijos redakcija.

Grossberg, L. (1996). Identity and cultural studies - Is that all there is? In S. Hall \& P. Du Gay (Eds.), Questions of Cultural Identity (pp. 87-107). London: Sage.

Hall, S. (1996). Who needs identity? In S. Hall \& P. Du Gay (Eds.), Questions of Cultural Identity (pp. 1-17). London: Sage. 
Vilma MIKAŠYTĖ

Johnston, H., \& Klandermans, B. (Eds.). (1995). Social movements and culture (social movements, protest, and contention). Minneapolis: University of Minnesota Press.

Kalnius, P. (2012). Žemaičiai: XX a. - XXI a. pradžia. Vilnius: Mintis.

Kamusella, T. (2001). Language as an instrument of nationalism in Central Europe. Nations and Nationalism, 2, 235-252.

Kliukienè, R. (2014). Kalbèjimas su tèvais tarmiškai ir gyventoju požiūris i tarmes Žemaitijos miestuose (kiekybinè analizè). Taikomoji kalbotyra, 5.

Law On the State Language. (1995). State Commission of the Lithuanian Language. Retrieved from http://www3.Irs.It/pls/inter/www_tv.show?id= 20034,1 .

Nayar, P. K. (2010). An introduction to new media and cyberculture. Malden: Wiley-Blackwell.

Nettle, D., \& Romaine, S. (2000). Vanishing voices. New York: Oxford UP.

Ramonienè, M. (2013). Tarmès socialinè vertè: Lietuvos miestu jaunimo kalbinès nuostatos. Taikomoji kalbotyra, 2

Ramonienè, M. (Ed.). (2010). Miestai ir kalbos. Vilnius: Vilnius UP.

Rheingold, H. (1993). The virtual community: Homesteading on the electronic frontier. MIT Press.

Rodham, K., \& Gavin, J. (2006). The ethics of using the internet to collect qualitative research data. Research Ethics Review, 2, 92-97.

Rosenberg, §. (2010). Virtual World Research Ethics and the Private/Public Distinction. International Journal of Internet Research Ethics, 3, 30-37.

Subačius, G. (2002). Two types of standard language history in Europe. Res Balticae, 8, 131-150.

Turkle, S. (1995). Life on the screen: Identity in the age of the internet. New York: Simon and Schuster.

Vaicekauskienè, L. (2011). Language 'nationalization': One hundred years of standard Lithuanian. In T. Kristiansen \& N. Coupland (Eds.) Standard Languages and Language Standards in a Changing Europe (pp. 105-112). Oslo: Novus.

Vaicekauskienè, L. (2012). Language standards in a post-modern speech community: Cosmetic touch ups and ongoing changes. Lituanus, 58, 5872. 
IS THE SAMOGITIAN DIALECT GOING TO DIE OUT? IMPLICATIONS OF SHOWING PRIDE IN BEING A SAMOGITIAN AND ATTITUDES TOWARDS SAMOGITIANNESS ON SAMOGITIAN FACEBOOK PAGES

Vandergriff, I., \& Fuchs, C. (2009). Does CMC promote language play? Exploring humor in two modalities. CALICO Journal, 27, 26-47.

Wilbur, S. B. (2000). An archaeology of cyberspace: Virtuality, community, identity. In D. Bell \& B. M. Kennedy (Eds.), The Cybercultures Reader (pp. 45-55). New York: Routledge.

Zimbra, D., Abbasi, A., \& Chen, H. (2010). A cyber-archaelogy approach to social movement research: Framework and case study. Journal of ComputerMediated Communication, 16, 48-70.

\section{Vilma Mikašytè}

Kauno technologijos universitetas, Lietuva; vilma.mikasyte@ktu.It

\section{AR ŽEMAIČIU TARMĖ IŠNYKS? DIDŽIAVIMOSI ESANT ŽEMAIČIU REIKŠMĖ BEI POŽIŪRIS I ŽEMAITIŠKUMA ŽEMAITIŠKUOSE PUSLAPIUOSE SOCIALINIAME TINKLE FACEBOOK}

Santrauka. Lietuviu kalbininkai mano, kad tarmès Lietuvoje gali išnykti. Mokslininkai, kurie visame pasaulyje dirba tam, kad užtikrintu kalbinės ivairovės išlaikyma, teigia, kad internetas suteikia nemokamas ir neribotas galimybes ta padaryti. Lietuvoje tarmiškai kalbantys žemaičiai naudojasi minètomis galimybèmis ir neseniai tapo ypač aktyvūs socialiniuose tinkluose. Jie populiarina tarmę, tarminius produktus, diskutuoja jiems svarbiomis, su tarme ir identitetu susijusiomis temomis. Straipsnyje aprašomi žemaitiško identiteto elementai, kurie pastebèti ištyrus žemaitišku turiniu besidalinančiu socialinio tinklo Facebook grupiu irašus ir komentarus. Tyrime naudojami metodai: kalbos palaikymas (angl. Language Maintenance), kiberkultūros metodas (angl. Cybercultures), diskurso analizè (angl. Discourse Analysis). Rezultatai atskleidžia, kad pagrindinis žemaitiško identiteto elementas - tarmè, dèl kurios, nepaisant didejjančios moralinès ir finansinès paramos, tarmiškai kalbantys žemaičiai vis dar jaučiasi stigmatizuojami. Visgi, žemaičiai labai palaiko vieni kitus ir skatina tarmę vartoti ne tik internete, bet ir realiame gyvenime. Tai, kad tiek daug žemaičiu išreiškia pasididžiavima tarme, yra geras ženklas tolesniam tarmès gyvavimui, o socialiniai tinklai yra vienas iš būdu, kuriuo tai gali būti užtikrinama.

Pagrindinès sąvokos: žemaičiu tarmè, Facebook, tarmiu palaikymas, identitetas. 